\title{
Evaluasi Pembelajaran Daring Mata Pelajaran Pendidikan Jasmani Olahraga dan Kesehatan SMA Pada Era Pandemi Covid-19
}

\author{
Wahyu Irfan Rojali ${ }^{1}$, Ngadiman ${ }^{2}$, Didik Rilastiyo Budi ${ }^{3}$, Panuwun Joko Nurcahyo ${ }^{4}$, \\ Ayu Rizky Febriani ${ }^{5}$ \\ ${ }^{12345}$ Fakultas Ilmu-Ilmu Kesehatan, Universitas Jenderal Soedirman, Indonesia. \\ E-mail: wahyuirfanrojali@gmail.com ${ }^{1}$
}

Menerima: 05 October 2020; Revisi: 23 March 2021; Diterima: 27 April 2021

do https://doi.org/10.24036/MensSana.06012021.24

\begin{abstract}
This study aims to evaluate learning from the subject of physical education, sports and high school's health during the Covid-19 pandemic in Brebes Regency. The data of this study are the main data obtained from the results of the questionnaire by the teachers of physical education and health (PJOK) and 32 Senior High School in Brebes. This study has 2 objective criteria, namely general and specific which is to determine the successful of the implementation of online learning in physical education subject in terms of several aspects, namely context, input, process, and product. This study uses a theory proposed by Sugiyono (2012). The research method used is descriptive quantitative. The result of this research is a recapitulation evaluation of 4 aspects of the teacher, namely $78.99 \%$ (good). Then, the overall online evaluation result is $68 \%$ (good enough). The conclusion of this study is that online learning of PJOK can be categorized with a good conclusion with a percentage of $73.5 \%$, but the product aspect is the lowest so that the product aspects need serious improvement and development in the online physical education learning program.
\end{abstract}

Keyword: Cipp, Online Learning, Physical Education

\section{Abstrak}

Penelitian ini bertujuan untuk mengevaluasi pembelajaran dari mata pelajaran pendidikan jasmani olahraga dan kesehatan SMA di masa pandemi Covid-19 di Kabupaten Brebes. Data dari penelitian ini adalah data pokok yang diperoleh dari hasil kuisioner oleh guru Pendidikan Jasmani Olahraga dan Kesehatan (PJOK) dan 32 SMA di kabupaten Brebes. Penelitian ini memiliki 2 kriteria tujuan yaitu secara umum dan khusus, yang mana untuk mengetahui keberhasilan pelaksanaan pembelajaran daring mata pelajaran PJOK di tinjau dari beberapa aspek, yaitu kontek, input, proses, dan produk. Penelitian ini menggunakan teori yang dikembangkan oleh Sugiyono (2012). Metode penelitian dari penelitian ini adalah metode deskriptif kuantitatif. Hasil dari penelitian ini adalah evaluasi rekapitulasi dari 4 aspek dari guru yaitu 78.99\% (baik) dan siswa 68\% (cukup). Serta hasil evaluasi dari keseluruhan yaitu $73.5 \%$ (baik). Kesimpulan dari penelitian ini adalah pembelajaran PJOK secara daring ternyata dapat dikategorikan dengan kesimpulan baik dengan prosentase $73.5 \%$, namun aspek produk menjadi terendah. Sehingga aspek produk membutuhkan perbaikan dan pengingkatan serius dalam program pembelajaran PJOK secara daring.

Kata Kunci: Cipp, Pembelajaran Daring, PJOK

\section{PENDAHULUAN}

Indonesia termasuk negara yang terkena dampak dari Corona Virus Desease 2019 (Covid-19). Pada akhir Desember 2019 wabah Covid-19 pertama kali muncul di China, wabah tersebut menyebar sangat cepat diberbagai negara, sehingga membuat WHO menetapkan peristiwa tersebut sebagai pandemic global. Melalui Kepres RI (2020) Nomor 11/2020 tentang Penetapan Kedaruratan Kesehatan Masyarakat, Pemerintah Indonesia memberlakukan kebijakan Pembatasan Sosial Berskala Besar (PSBB) untuk menekan penyebaran Covid-19. Terkait proses pembelajaran di sekolah, melalui Surat Edaran Mendikbud R.I (2020) Nomor: 36962/MPK.A/HK/2020, pemerintah memberlakukan Pembelajaran Secara Jarak Jauh 
Wahyu Irfan Rojali ${ }^{1}$, Ngadiman ${ }^{2}$, Didik Rilastiyo Budi ${ }^{3}$, Panuwun Joko Nurcahyo ${ }^{4}$, Ayu Rizky Febriani ${ }^{5}$

dalam Rangka Pencegahan Penyebaran COVID19.

Kebijakan mengenai pelaksanaan pembelajaran daring diberlakukan di beberapa daerah di Indonesia termasuk Kabupaten Brebes. Sesuai Perbup Brebes (2020) Nomor 54 Pasal 8 ayat 1 Tahun 2020 Tentang Pedoman Tatanan Normal Baru pada Kondisi Pandemi Corona Virus Desease 2019 di Kabupaten Brebes dinyatakan bahwa pelaksanaan pembelajaran sebagaimana dimaksud Pasal 7 huruf a, diutamakan melalui pelaksanaan belajar dari rumah dengan metode pembelajaran jarak jauh/daring. Tetapi hal tersebut tidak berlaku bagi daerah yang belum siap dengan sistem pembelajaran daring yang menuntut siswa maupun guru membutuhkan fasilitas pembelajaran (handphone dan koneksi internet).

Proses pembelajaran pada mata pelajaran PJOK sudah biasa dikaitkan dengan pembelajaran tatap muka yang menyenangkan dan menggembirakan (Budi et al., 2019; Kusnandar, Friskawati et al., 2021; Nur et al., 2020). Pada masa darurat penyebaran Covid-19 pembelajaran PJOK dilaksanakan secara jarak jauh atau daring, guru pun harus siap memodifikasi materi ajar dan berinovasi untuk memaksimalkan pembelajaran secara daring. Modifikasi pembelajaran menjadi salah satu solusi apabila proses pembelajaran penjas apabila situasi kurang mendukung (Budi, 2015; Setawan et al., 2020; Widowati \& Decheline, 2020)

Potensi pembelajaran untuk mata pelajaran PJOK pada masa penyebaran Covid-19 sangat terbuka, meskipun wilayah serta lingkungan sekolah tidak dilengkapi sarana dan prasarana penunjang untuk pembelajaran daring (Herlina dan Suherman, 2020). Pembelajaran tetap dapat dilakukan dengan model pembelajaran jarak jauh (distance learning) dan menggagas pendekatan kolaboratif (collaborative approach) dengan orang tua siswa yang melakukan pengamatan aktivitas belajar siswa. Faktor lingkungan belajar sangat berpengaruh pada saat pembelajaran daring (Wekke dan Saleh, 2020). Siswa yang berada di pelosok desa dengan kondisi yang serba terbatas dalam hal pendidikan maupun teknologi tentunya akan berbeda dengan siswa yang berada di pusat kota dengan kondisi ekonomi keluarga yang baik untuk mengakses pembelajaran daring tersebut.

Pelaksanaan pembelajaran daring mata pelajaran PJOK pada masa penyebaran Covid-19 masih banyak persoalan dan hambatan yang mempengaruhi hasil belajar siswa. Purwanto et al. (2020) dan Muhammad \& Budi (2020) menyatakan bahwa siswa belum memiliki budaya belajar secara daring karena selama ini sistem pembelajaran dilaksanakan secara tatap muka secara langsung di sekolah. Metode pembelajaran penjas secara daring membuat siswa harus beradaptasi dalam menghadapi perubahan lingkungan belajar (Raibowo, Septian; Nopiyanto, 2020).

Perubahan baru tersebut secara tidak langsung mampu mempengaruhi tingkat pengetahuan, pemahaman dan hasil belajar siswa. Berdasarkan kondisi tersebut maka, masih perlu kajian untuk mengetahui bagaimana pelaksanaan pembelajaran daring PJOK pada masa penyebaran Covid-19 melalui sebuah penelitian evaluasi. Penelitian evaluasi adalah penelitian untuk mengungkapkan gejala-gejala pada saat evaluasi berlangsung (Khamidah dan Aprilia, 2014). Gejala tersebut tentunya berkaitan dengan pembelajaran daring pada masa penyebaran Covid-19. Dalam mengungkapkan gejala-gejala sangat diperlukan evaluasi secara baik dan menyeluruh dengan tujuan untuk mengetahui keberhasilan pelaksanaan pembelajaran.

Menurut Widyoko (2009) menyatakan bahwa untuk mengevaluasi keberhasilan pembelajaran tidak cukup dengan hanya melakukan penilaian hasil belajar siswa, akan tetapi perlu menjangkau terhadap desain program dan implementasi program pembelajaran. Hal tersebut juga dimaksudkan untuk memahami, menggali, serta megoreksi program pembelajaran yang telah berlangsung agar dapat diketahui celah-celah kekurangannya dan dapat dikoreksi serta diperbaiki. Untuk memperbaiki kekurangan dalam program pembelajaran daring tentunya diperlukan pendekatan dengan model-model evaluasi.

Beberapa model evaluasi yang bisa digunakan antara lain evaluasi model Provus, evaluasi model Kirkpatrick, dan evaluasi model CIPP. Model context, input, process, product (CIPP) adalah salah satu model evaluasi program yang dikembangkan oleh Stufflebeam (2000). Konsep inti model ini adalah konteks, input, proses, dan evaluasi produk. Dengan menggunakan empat jenis evaluasi, evaluator menjalankan beberapa fungsi penting. Model evaluasi ini dipilih karena konsepnya yang menawarkan pandangan bahwa tujuan penting evaluasi yaitu bukan membuktikan melainkan untuk memperbaiki. Evaluasi ini dapat diterapkan 
dalam beberapa bidang, seperti pendidikan, manajemen, dan institusi.

Penelitian ini bertujuan untuk mengevaluasi pembelajaran daring mata pelajaran pendidikan jasmani olahraga dan kesehatan (PJOK) ditingkat Sekolah Menengah Atas (SMA) pada era pandemi Covid-19 di Kabupaten Brebes Jawa Tengah. Melalui penelitian ini diharapkan dapat diketahui pelaksanaan pembelajaran daring yang sedang diterapkan sudah efektif atau belum, khususnya di tingkat Sekolah Menengah Atas (SMA).

\section{METODE}

Penelitian ini adalah penelitian deskriptif kuantitatif yaitu penelitian yang kemudian diolah dan dianalisis untuk mengambil kesimpulan (Sugiyono, 2016). Artinya penelitian yang dilakukan yaitu penelitian yang menekankan analisisnya pada data-data angka. Berdasarkan tujuannya maka penelitian ini tergolong penelitian evaluatif yang bertujuan untuk mengetahui pelaksanaan sebuah program kegiatan. Model evaluasi yang akan digunakan pada penelitian ini yaitu model CIPP (context, input, process, product) berkaitan dengan pelaksanaan pembelajaran daring.

Penelitian ini dilaksanakan di Kabupaten Brebes pada guru pendidikan jasmani olahraga dan kesehatan, dan siswa SMA yang mengambil mata pelajaran pendidikan jasmani olahraga dan kesehatan, yang mana telah melaksanakan pembelajaran secara daring. Pengambilan data serta waktu penelitian dilaksanakan pada bulan November dan Desember 2020.

Populasi dalam penelitian ini merujuk dari data pokok pendidikan Kementerian Pendidikan dan Kebudayaan Republik Indonesia yaitu seluruh guru pendidikan jasmani olahraga dan kesehatan dan seluruh siswa dari 32 SMA di Kabupaten Brebes. Teknik atau pengambilan sampel yang digunakan dalam penelitian ini adalah cluster random sampling. Kurniawan (2018) menyatakan bahwa cluster random sampling adalah teknik pengambilan sampel dari populasi yang terdiri dari klaster-klaster tertentu, bukan terdiri dari individu-individu.

Kemudian berdasarkan random terhadap 32 SMA di Kabupaten Brebes, maka diperoleh sampel penelitian sebanyak 3 SMA dengan pertimbangan bahwa setiap SMA tersebut mewakili wilayah geografis yang ada di
Kabupaten Brebes, dimana setiap wilayah tentu berbeda dalam mengakses kecepatan internet. Jumlah sampel siswa dari 3 SMA tersebut akan ditentukan dengan Proportionate Random Sampling, sedangkan jumlah sampel guru PJOK dari 3 SMA tersebut menggunakan total sampling. Adapun ketiga sekolah yang terpilih secara random menjadi sampel dan jumlah sampel guru dan siswa sebagaimana dalam tabel 1 dan 2 dibawah ini.

Tabel 1. Nama Sampel SMA dan Jumlah Sampel Guru

\begin{tabular}{llcc}
\hline No & \multicolumn{1}{c}{ Nama Sekolah } & Populasi & Sampel \\
\hline 1 & SMA Negeri 1 Brebes & 4 & 4 \\
2 & $\begin{array}{l}\text { SMA Negeri } \\
\text { Bulakamba }\end{array}$ & 4 & 4 \\
3 & $\begin{array}{l}\text { SMA Islam T. Huda } \\
\text { Bumiayu } \\
\text { JUMLAH }\end{array}$ & 2 & 2 \\
& & 10 & 10 \\
\hline
\end{tabular}

Tabel 2. Nama Sampel SMA dan Jumlah Sampel Siswa

\begin{tabular}{llcc}
\hline No & \multicolumn{1}{c}{ Nama Sekolah } & Populasi & Sampel \\
\hline 1 & SMA Negeri 1 Brebes & 1.166 & 41 \\
2 & SMA Negeri 1 Bulakamba & 1.165 & 41 \\
3 & SMA Islam T. Huda & 501 & 18 \\
& Bumiayu & & \\
\multicolumn{2}{c}{ JUMLAH } & 2.832 & 100 \\
\hline
\end{tabular}

Instrumen penelitian menggunakan kuesioner. Kuesioner merupakan teknik pengumpulan data yang dilakukan dengan cara memberi seperangkat pertanyaan atau pernyataan tertulis kepada responden untuk dijawabnya (Sugiyono, 2012). Intrumen penelitian ini menggunakan CIPP (context, input, process, product) yang dikembangkan oleh (Stufflebeam, 2000) dimana responden memiliki empat jawaban yang tersedia yaitu: (1) Sangat Setuju mendapat point 4; (2) Setuju mendapat point 3; (3) Tidak Setuju mendapat point 2; (4) Sangat Tidak Setuju mendapat point 1. Instrumen kuesioner guru memiliki nilai validitas 0,637 dan kuesioner siswa memiliki nilai validitas 0,667. Reliabilitas intrumen pada kuesioner guru memiliki nilai 0,943 dan kuesioner siswa 0,951 dengan kategori tinggi.

Jenis analisis data yang digunakan adalah Statistik deskriptif. Statistik deskriptif adalah statistik yang digunakan untuk menganalisis data 
Wahyu Irfan Rojali ${ }^{1}$, Ngadiman ${ }^{2}$, Didik Rilastiyo Budi ${ }^{3}$, Panuwun Joko Nurcahyo ${ }^{4}$, Ayu Rizky Febriani ${ }^{5}$

dengan cara mendeskripsikan atau menggambarkan data yang telah terkumpul (Sugiyono, 2012). Data kuesioner dianalisis menggunakan rumus $\mathrm{P}=\mathrm{f} / \mathrm{n} \quad \mathrm{x} \quad 100 \%$. Selanjutnya untuk menjawab tentang deskripsi evaluasi pembelajaran daring, dibuat skor-skor perolehan yang dikategorikan dengan menggunakan Penilaian Acuan Patokan (PAP). Kriteria PAP berdasarkan Ngelo (2005) tertera pada table 3 dibawah ini.

Tabel 3. Penilaian Acuan Patokan (PAP)

\begin{tabular}{lc}
\hline Kriteria & Presentase (\%) \\
\hline Sangat Baik & $85-100$ \\
Baik & $70-84$ \\
Cukup & $55-69$ \\
Tidak Baik & $40-54$ \\
Sangat Tidak Baik & $0-39$ \\
\hline
\end{tabular}

Penelitian ini dilaksanakan dengan melalui beberapa proses dan mempertimbangkan beberapa hal, diantaranya yaitu peneliti mengajukan uji etik, dan mendapatkan persetujuan etik dari komisi etik Fakultas Ilmuilmu Kesehatan Universitas Jenderal Soedirman

\begin{tabular}{cccccc}
\hline No & Aspek & \multicolumn{2}{c}{ Responden } & $\begin{array}{c}\text { Rata- } \\
\text { rata }\end{array}$ & Kategori \\
\cline { 3 - 4 } & & Guru & Siswa & & \\
\hline 1 & Context & $82,5 \%$ & $70 \%$ & $76,2 \%$ & Baik \\
2 & Input & $81,38 \%$ & $71,96 \%$ & $76,6 \%$ & Baik \\
3 & Process & $83,33 \%$ & $68,5 \%$ & $75,9 \%$ & Baik \\
4 & Product & $68,75 \%$ & $62 \%$ & $65,3 \%$ & Cukup \\
\hline & & & & & Baik
\end{tabular}

dengan nomor 232/EC/KEPK/XII/2020.

\section{HASIL DAN PEMBAHASAN \\ Hasil Penelitian}

Data hasil penelitian mengenai evaluasi pembelajaran daring terhadap 10 Guru yang terbagi dari 4 Guru (SMAN 1 Brebes), 4 Guru (SMAN 1 Bulakamba), dan 2 Guru (SMA Islam Taalamul Huda Bumiayu) dapat dilihat pada tabel berikut.

\section{Tabel 4. Rekapitulasi Hasil Evaluasi Pembelajaran Daring Terhadap Guru}

Berdasarkan data yang disajikan tabel 4 dapat diketahui bahwa aspek Context mendapatkan nilai indeks $82,50 \%$ dengan kategori baik, aspek Input mendapatkan nilai indeks $81,38 \%$ dengan kategori baik, aspek Process mendapatkan nilai indeks 83,33\% dengan kategori baik, aspek Product mendapatkan nilai indeks $68,75 \%$ dengan kategori cukup. Dengan demikian evaluasi pembelajaran daring terhadap guru mendapatkan

\begin{tabular}{clcccc}
\hline No & Aspek & $\begin{array}{c}\text { Skor } \\
\text { Perolehan }\end{array}$ & $\begin{array}{c}\text { Skor } \\
\text { Maksimum }\end{array}$ & $\begin{array}{c}\text { Indeks } \\
(\%)\end{array}$ & $\begin{array}{c}\text { Kateg } \\
\text { ori }\end{array}$ \\
\hline 1 & Context & 2240 & 3200 & $70 \%$ & Baik \\
2 & Input & 3742 & 5200 & $71,96 \%$ & Baik \\
3 & Process & 1645 & 2400 & $68,5 \%$ & Cukup \\
4 & Product & 1489 & 2400 & $62 \%$ & Cukup \\
\hline & Jumlah & & $68 \%$ & Cukup \\
\hline
\end{tabular}

nilai indeks 78,99 sehingga termasuk dalam kategori baik.

Data hasil penelitian mengenai evaluasi pembelajaran daring terhadap 100 Siswa yang terbagi dari 41 Siswa (SMAN 1 Brebes), 41 Siswa (SMAN 1 Bulakamba), dan 18 Siswa (SMA Islam Taalamul Huda Bumiayu) dapat dilihat pada tabel berikut.

Tabel 5. Rekapitulasi Hasil Evaluasi Pembelajaran Daring Terhadap Siswa

Berdasarkan data yang disajikan tabel 5 dapat diketahui bahwa aspek Context mendapatkan nilai indeks $70 \%$ dengan kategori Baik, aspek Input mendapatkan nilai indeks 71,96\% dengan kategori Baik, aspek Process mendapatkan nilai indeks $68,5 \%$ dengan kategori Cukup, aspek Product mendapatkan nilai indeks $62 \%$ dengan kategori Cukup. Dengan demikian evaluasi pembelajaran daring terhadap siswa mendapatkan nilai indeks $68 \%$ dengan kategori Cukup.

Tabel 6. Hasil Evaluasi Pembelajaran Daring Keseluruhan

\begin{tabular}{clcccc}
\hline No & Aspek & $\begin{array}{c}\text { Skor } \\
\text { Perolehan }\end{array}$ & $\begin{array}{c}\text { Skor } \\
\text { Maksimum }\end{array}$ & $\begin{array}{c}\text { Indeks } \\
(\mathbf{\%})\end{array}$ & $\begin{array}{c}\text { Kateg } \\
\text { ori }\end{array}$ \\
\hline 1 & Context & 165 & 200 & $82,5 \%$ & Baik \\
2 & Input & 293 & 360 & $81,38 \%$ & Baik \\
3 & Process & 300 & 360 & 83,33 & Baik \\
4 & Product & 110 & 160 & $68,75 \%$ & Cukup \\
\hline & Jumlah & & & $78,99 \%$ & Baik \\
\hline
\end{tabular}

Berdasarkan data yang disajikan tabel 6

dapat diketahui bahwa aspek Context mendapatkan rata-rata $76,2 \%$ dengan kategori Baik, aspek Input mendapatkan rata-rata 76,6\% dengan kategori Baik, aspek Process mendapatkan rata-rata $75,9 \%$ dengan kategori Baik, aspek Product mendapatkan nilai indeks 65,3\% dengan kategori Cukup. Dengan demikian secara keseluruhan evaluasi pembelajaran daring mendapatkan nilai indeks $73,5 \%$ dengan kategori baik. 


\section{Pembahasan \\ Aspek Context}

Evaluasi pembelajaran daring pada aspek Context memperoleh nilai indeks keseluruhan sebesar 76,2\%, sehingga termasuk ke dalam kategori baik. Hal ini sejalan dengan penelitian Riyanda et al, (2020) tentang "Evaluasi Implementasi Sistem Pembelajaran Daring Fakultas Keguruan dan Ilmu Pendidikan Universitas Lampung" yang memperoleh hasil baik. Artinya pada aspek ini pendidik menyadari bahwa kebutuhan pembelajaran daring diperlukan sebagai alternatif pembelajaran luring. Menurut Zhang et al, (2004) menyatakan bahwa penggunaan internet dan teknologi multimedia mampu merombak cara penyampaian pengetahuan dan dapat menjadi alternatif pembelajaran yang dilaksanakan dalam kelas.

Pembelajaran daring juga dianggap sudah memenuhi hak siswa mendapatkan layanan pendidikan. Namun ada beberapa siswa yang menganggap bahwa kualitas pembelajaran daring belum sesuai kebutuhan belajar, hal tersebut tentunya harus menjadi fokus sekolah atau institusi terkait. Prayitno et al, (2018) menyatakan bahwa untuk meningkatkan kualitas pembelajaran tentunya diperlukan sosialisasi dan pelatihan TIK secara mendalam kepada guru dan siswa. Peningkatan lain yang dapat dilakukan yaitu sekolah memberikan edukasi kepada siswa agar pembelajaran daring bisa berjalan efektif tanpa ada penyalahgunaan teknologi. Sehingga kebutuhan belajar siswa diharapkan bisa terpenuhi.

\section{Aspek Input}

Evaluasi pembelajaran daring pada aspek Input memperoleh nilai indeks keseluruhan sebesar $76,6 \%$, sehingga termasuk ke dalam kategori baik. Hal ini tidak jauh berbeda dengan penelitian Ahmadi dan Wakid (2016) yang memperoleh nilai 65,XMR juga sangat baik dalam penggunaan teknologi sehingga nilai yang didapat dari aspek Input sudah termasuk dalam kategori baik. Namun ada beberapa siswa yang belum mahir dalam penggunaan teknologi, Menurut Dewi (2020) menyatakan bahwa belajar daring (online) dapat menggunakan teknologi digital seperti google classroom, rumah belajar, zoom, video conference, telepon atau live chat dan lainnya. Namun yang pasti harus dilakukan adalah pemberian tugas melalui pemantauan pendampingan oleh guru melalui whatsapp grup sehingga anak dapat berkonsentrasi dalam belajar.

Menurut Ahmadi dan Wakid (2016) menyatakan bahwa guru memiliki peran besar dalam meningkatkan pengetahuan pembelajaran daring, jika guru rutin memberi tugas dalam $e$ learning maka secara otomatis siswa akan lebih mahir dalam penggunaan fitur-fitur pembelajaran daring. Selain itu siswa juga harus meningkatkan semangat belajarnya sehingga hubungan guru dan siswa berjalan dengan baik. Sekolah diharapkan bisa ikut berkontribusi, Salah satu yang bisa dilakukan sekolah yaitu dengan melakukan pelatihan lebih lanjut mengenai penggunaan teknologi berupa penggunaan aplikasi dan lainnya serta pelatihan fitur-fitur yang menarik untuk disajikan kepada siswa.

\section{Aspek Process}

Evaluasi pembelajaran daring pada aspek Process memperoleh nilai rata-rata indeks sebesar $75,9 \%$, sehingga termasuk ke dalam kategori baik, hal ini sejalan dengan penelitian Riyanda et al, (2020) tentang "Evaluasi Implementasi Sistem Pembelajaran Daring Fakultas Keguruan dan Ilmu Pendidikan Universitas Lampung" yang memperoleh hasil baik. Artinya pendidik dan siswa dapat memanfaatkan fasilitas pendukung pembelajaran dengan baik, namun pada proses pembelajaran daring masih terdapat beberapa siswa yang kurang disiplin sehingga akan lebih baik pada aspek ini dilakukan peningkatan.

Kedisiplinan yang kurang tentunya terjadi karena beberapa faktor. Menurut Fikri (2016) menyatakan bahwa ketidakdisiplinan siswa dalam pembelajaran disebabkan oleh model pembelajaran yang diterapkan oleh guru tidak menarik perhatian siswa. Artinya model pembelajaran sangat penting agar proses pembelajaran bisa berjalan dengan baik, hal ini juga menjadi tanggung jawab sekolah untuk menemukan model-model atau media-media terbaru yang dapat di aplikasikan pada pembelajaran daring.

Sudrajad (2011) menyatakan bahwa media pembelajaran merupakan segala sesuatu yang digunakan untuk menyalurkan pesan, dapat merangsang pikiran, perasaan, dan kemampuan peserta didik sehingga dapat mendorong tercapainya proses belajar pada 
Wahyu Irfan Rojali ${ }^{1}$, Ngadiman ${ }^{2}$, Didik Rilastiyo Budi ${ }^{3}$, Panuwun Joko Nurcahyo ${ }^{4}$, Ayu Rizky Febriani ${ }^{5}$

peserta didik.

\section{Aspek Product}

Evaluasi pembelajaran daring pada aspek Product memperoleh nilai rata-rata indeks sebesar $65,3 \%$, sehingga termasuk ke dalam kategori Cukup, hal ini hampir sama dengan penelitian Raibowo dan Nopiyanto (2020) tentang "Evaluasi Pembelajaran Pendidikan Jasmani Olahraga dan Kesehatan pada SMP Negeri se-Kabupaten Mukomuko melalui pendekatan model CIPP" yang memperoleh hasil kurang baik. Artinya hasil dari pembelajaran daring membuat siswa memahami materi dengan baik, namun beberapa guru beranggapan bahwa pada hasil belajar serta motivasi siswa menurun.

Menurut Slameto (2010) menyatakan bahwa faktor yang memengaruhi hasil belajar dibedakan menjadi dua yaitu faktor internal dan faktor eksternal. Faktor internal adalah faktor yang berasal dari dalam diri siswa, seperti disiplin belajar, kondisi fisiologis (keadaan fisik siswa), kondisi psikologi (kecerdasan, bakat, minat, motivasi). Faktor eksternal adalah faktor yang berasal dari luar diri siswa, seperti faktor lingkungan, keluarga, alat instrument (kurikulum, sarana dan prasarana serta pendidik). Hal ini bisa menjadi fokus utama untuk mencari solusi memperbaikinya.

Menurut Clemente et al, (2012) menyatakan bahwa penggunaan beragam model dalam pembelajaran akan memberikan motivasi siswa dalam belajar pendidikan jasmani. Untuk itu guru dapat memberikan model atau metode yang tidak biasa dengan metode sebelumnya seperti pemberian tugas kelompok berupa pembuatan video melalui aplikasi yang tersedia pada smartphone siswa serta bisa dilakukan feedback untuk bisa melihat video tersebut bersama-sama. Kemudian untuk hasil belajar siswa, pihak sekolah bisa meninjau Kembali standar nilai yang biasa digunakan pada pembelajaran luring. Perbaikan yang dapat dilakukan guru yaitu dengan memodifikasi metode serta materi belajar agar semangat belajar serta motivasi siswa meningkat, sehingga hal tersebut diharapkan bisa meningkatkan hasil belajar siswa.

\section{KESIMPULAN}

Berdasarkan hasil penelitian dan pembahasan yang telah dilakukan secara keseluruhan keberhasilan pembelajaran daring PJOK pada SMA di Kabupaten Brebes yang ditinjau_dari_aspek Context, Input, Process, dan Product diperoleh hasil dengan kategori baik.
Namun dari keempat aspek tersebut aspek product mendapatkan hasil terendah. Oleh karena itu, aspek tersebut membutuhkan perbaikan dan peningkatan lebih serius agar program pembelajaran daring dapat terlaksana dengan lebih baik.

Berdasarkan hasil penelitian dan pembahasan yang telah dilakukan, maka saransaran yang peneliti ajukan yaitu, guru SMA di Kabupaten Brebes disarankan untuk lebih meningkatkan penguasaan teknologi serta penguasaan penyampaian materi agar penerapan pembelajaran daring pada SMA di Kabupaten Brebes dapat terlaksana dengan lebih baik. Siswa SMA di Kabupaten Brebes sebagian besar sudah baik dalam proses pembelajaran, alan tetapi siswa disarankan untuk lebih bersungguh-sungguh dalam mengikuti pembelajaran serta meningkatkan motivasi belajar dengan tujuan untuk meningkatkan hasil belajar siswa.

\section{DAFTAR PUSTAKA}

Budi, Didik Rilastiyo, Kusuma, M. N. H., Syafei, M., \& Stephani, M. R. (2019). The Analysis of Fundamental Movement Skill in Primary School Student in Mountain Range. 11 (Icsshpe 2018), 195-198. https://doi.org/10.2991/icsshpe-18.2019.56

Budi, Didik Rilastyo. (2015). Pengaruh Modifikasi Permainan Vobas dan Kebugaran Jasmani Terhadap Peningkatan Kerjasama Siswa dalam Pembelajaran Penjas di SMP. Thesis.

Clemente, F., Rocha, R. F., \& Korgaokar, A. (2012). Teaching physical education: the usefulness of the teaching games for understanding and the constraints-led approach. Journal of Physical Education and Sport, 12(4), 417.

Dewi, W. A. F. (2020). Dampak Covid-19 terhadap implementasi pembelajaran daring di Sekolah Dasar. Edukatif: Jurnal Ilmu Pendidikan, 2(1), 55-61.

Fikri, A. \& M. (2016). The Application of Game Models to Promote Student Participation in Learning Rounders Game Activities',. Jurnal Pendidikan Jasmani Dan Olahraga, $1(1)$.

Herlina, H., \& Suherman, M. (2020). Potensi Pembelajaran Pendidikan Jasmani Olahraga 
Dan Kesehatan (Pjok) Di Tengah Pandemi Corona Virus Disease (Covid)-19 Di Sekolah Dasar. Tadulako Journal Sport Sciences And Physical Education, 8(1), 17.

Khamidah, N., \& Aprilia, N. (2014). Evaluasi Program Pelaksanaan Praktikum Biologi Kelas XI SMA Se-Kecamatan Umbulharjo Yogyakarta Semester II Tahun Ajaran 2013/2014. Jupemasi-Pbio, 1(1), 5-8.

Kurniawan, A. (2018). Metodologi Penelitian Pendidikan. PT Remaja Rosdakarya.

Kusnandar, Friskawati GF, Kharisman, V.A., \& Budi, D.R. (2021): Elementary student's physical activity during pandemic Covid 19. Ann Trop Med \& Public Health; 24(S03):

SP24329. DOI:http://doi.org/10.36295/ASRO.2021.2 4329

Mendikbud R.I. (2020). Tentang Pemberlakuan Pembelajaran Secara Daring dan Bekerja dari Rumah dalam Rangka Pencegahan Penyebaran COVID-19. Tentang Pemberlakuan Pembelajaran Secara Daring Dan Bekerja Dari Rumah Dalam Rangka Pencegahan Penyebaran COVID19.

Muhammad, H. N., \& Budi, D. R. (2020). Bunga Rampai Strategi, Proses, Evaluasi, dan Pembelajaran Pendidikan Jasmani, Olahraga dan Kesehatan (PJOK) pada era pandemi covid-19. Unesa University Press.

Ngelo, J. \& Y. (2005). Penerapan Pendekatan Pembelajaran Kontruktivisme untuk Meningkatkan Keefektifan dan Hasil Belajar Mata Pelajaran Sains pada Siswa Kelas V Semester II Tahun Pelajaran 2004/2005 di Sekolah Dasar No 2 Canggu Kecamatan Kuta Utara Kabupaten Badung. Jurusan Teknologi Pendidikan Universitas Pendidikan Ganesha.

Nur, L., Malik, A. A., Juditya, S., Kastrena, E., Widyawan, D., Agustan, B., Budi, D. R., Ardha, M. A. Al, \& Yang, C. B. (2020). Comparison of two types of instruction in physical education. International Journal of Psychosocial Rehabilitation, 24(10), 17851793. https://doi.org/10.37200/IJPR/V24I10/PR3 00205

Perbup Brebes. (2020). Peraturan Bupati Brebes Nomor 54 Pasal 8 Ayat 1 Tahun 2020 Tentang Pedoman Tatanan Normal Baru Pada Kondisi Pandemi Corona Virus Desease 2019 Di Kabupaten Brebes.

Prayitno, E., Kurniawati, D., \& Arvianto, I. R. (2018). Pemanfaatan Teknologi Informasi dan Komunikasi (TIK) Untuk Meningkatkan Kualitas Pembelajaran. Seminar Nasional Call For Paper \& Pengabdian Masyarakat, 1(01).

Purwanto, A., Pramono, R., Asbari, M., Hyun, C. C., Wijayanti, L. M., \& Putri, R. S. (2020). Studi eksploratif dampak pandemi COVID19 terhadap proses pembelajaran online di sekolah dasar. EduPsyCouns: Journal of Education, Psychology and Counseling, 2(1), 1-12.

Raibowo, Septian; Eko Nopiyanto, Y. (2020). PROSES BELAJARMENGAJARPJOK DI MASA PANDEMI COVID-19. Journal STAND, 1, 49-55.

Raibowo, S., \& Nopiyanto, Y. E. (2020). Evaluasi Pembelajaran Pendidikan Jasmani Olahraga \& Kesehatan pada SMP Negeri Se-Kabupaten Mukomuko melalui Pendekatan Model Context, Input, Process $\&$ Product (CIPP). Jurnal Pendidikan Kesehatan Rekreasi, 6(2), 146-165.

RI, K. S. N. (2020). KEPRES Nomor 11 Tahun 2020 Tentang PENETAPAN KEDARURATAN KESEHATAN MASYARAKAT CORONA VIRUS DISEASE 2019 (COVID-19).

Riyanda, A. R., Herlina, K., \& Wicaksono, B. A. (2020). Evaluasi Implementasi Sistem Pembelajaran Daring Fakultas Keguruan Dan Ilmu Pendidikan Universitas Lampung. IKRA-ITH HUMANIORA: Jurnal Sosial Dan Humaniora, 4(1), 66-71. 
Setiawan, A., Yudiana, Y., Ugelta, S., Oktriani, S., Budi, D. R., \& Listiandi, A. D. (2020). Hasil Belajar Pendidikan Jasmani dan Olahraga Siswa Sekolah Dasar: Pengaruh Keterampilan Motorik (Tinggi) dan Model Pembelajaran (Kooperatif). TEGAR: Journal of Teaching Physical Education in Elementary School. https://doi.org/10.17509/tegar.v3i2.24513

Slameto. (2010). Belajar dan faktor-faktor yang mempengaruhinya. Rineka Cipta.

Stufflebeam, D. L. (2000). The CIPP model for evaluation. In Evaluation models (pp. 279317). Springer.

Sudrajad, A. (2011). Kurikulum dan Pembelajaran dalam Paradigma Baru. Paramitra Publishing.

Sugiyono. (2012). Metode Penelitian Pendidikan. Alfabeta.

Sugiyono, P. D. (2016). metode penelitian kuantitatif, kualitatif,dan R\&D. In Alfabeta, $c v$. Alfabeta.

Wekke, I. S., \& Saleh, A. M. (2020). Pembelajaran di Masa Pandemi: Tidak Hanya Metode Daring Saja.

Widowati, A., \& Decheline, G. (2020). Modifikasi Senjata Anggar Untuk Meningkatkan Kekuatan Otot Lengan Pada Atlet Anggar Pemula. Physical Activity Journal, 2(1), 109. https://doi.org/10.20884/1.paju.2020.2.1.33 31

Widyoko, E. (209 C.E.). Evaluasi Program Pembelajaran. Pustaka Pelajar.

Zhang, et al. (2004). Can e-learning replace classroom learning? Communications of the $A C M, 47,5$. 